\title{
The antifungal effect of cellobiose lipid on the cells of Saccharomyces cerevisiae depends on carbon source
}

\author{
Ludmila V Trilisenko ${ }^{1}$, Ekaterina V Kulakovskaya ${ }^{1}$, Tatiana V Kulakovskaya ${ }^{* *}$, Alexander Yu Ivanov² ${ }^{2}$ Nikita V Penkov², \\ Vladimir M Vagabov ${ }^{1}$ and Igor S Kulaev ${ }^{1}$
}

\begin{abstract}
The cellobiose lipid of Cryptococcus humicola, 16-(tetra-O-acetyl-ß-cellobiosyloxy)-2-hydroxyhexadecanoic acid, is a natural fungicide. Sensitivity of the cells of Saccharomyces cerevisiae to the fungicide depends on a carbon source. Cellobiose lipid concentrations inducing the leakage of potassium ions and ATP were similar for the cells grown in the medium with glucose and ethanol. However, the cells grown on glucose and ethanol died at $0.05 \mathrm{mg} \mathrm{ml}^{-1}$ and $0.2 \mathrm{mg} \mathrm{ml}^{-1}$ cellobiose lipid, respectively. Inorganic polyphosphate (PolyP) synthesis was 65\% of the control with $0.05 \mathrm{mg} \mathrm{ml}^{-1}$ cellobiose lipid during cultivation on ethanol. PolyP synthesis was not observed during the cultivation on glucose at the same cellobiose lipid concentration. The content of longer-chain polyP was higher during cultivation on ethanol. We speculate the long-chained polyP participate in the viability restoring of ethanol-grown cells after treatment with the cellobiose lipid.
\end{abstract}

Keywords: Cellobiose lipid, Fungicide, Cryptococcus humicola, Saccharomyces cerevisiae, ATP, Potassium ion, Inorganic polyphosphate, Carbon source

\section{Background}

Some yeasts and mycelial fungi produce glycolipids of various types such as mannosylerythritols, sophorolipids, and cellobiose lipids. They possess multiple biological activities: they act as biosurfactants, facilitate dissolution and consumption of organic hydrophobic compounds, and display fungicidal activity (Kitamoto et al. 2002; Cameotra and Makkar 2004; Golubev 2006; Rodrigues et al. 2007). Cellobiose lipids display antifungal activity against many species of ascomycetous and basidiomycetous yeast and mycelial fungi including know pathogens, Filobasidiella (Cryptococcus) neoformans and Candida albicans (Puchkov et al. 2002; Kulakovskaya et al. 2005, 2009; Mimee et al. 2005; Bölker et al. 2008; Hammami et al. 2010, 2011). The broad spectrum of activity, $\mathrm{pH}$ and temperature stability allows considering cellobiose lipids as promising compounds for the development of novel fungicides for medical and agricultural

\footnotetext{
* Correspondence: alla@ibpm.pushchino.ru

'Skryabin Institute of Biochemistry and Physiology of Microorganisms, Russian Academy of Sciences, Pushchino, Moscow Region 142290, Russia Full list of author information is available at the end of the article
}

applications. So, many studies are now performed in their biochemistry, genetics and possible ecology role (Teichmann et al. 2007, Bölker et al. 2008; Hammami et al. 2010, 2011).

The mechanism of action of cellobiose lipids on yeast cells is based on enhancement of nonspecific permeability of the cytoplasmic membrane, which results in the rapid leakage of ATP and potassium ions from the yeast cells treated with these compounds (Kulakovskaya et al. 2005, 2008). The glycolipids are surface-active compounds reducing the surface tension of water solutions. Cellobiose lipids of Cr. humicola have a high surface activity comparable with that of SDS (Puchkov et al. 2002). The intercalation of glycolipid of Cr. humicola into liposomes containing diphytanoylphosphatidylcholine, ergosterol, and phosphatydilserine was demonstrated (Puchkov et al. 2002). These data suggest that the mycocidal effect of cellobiose lipids is associated with its detergent-like properties. Based on these observations and on the electrical measurements on planar phospholipid bilayers, which showed glycolipid-induced membrane permeabilization, it was suggested that the cytoplasmic membrane is the

\section{Springer}


primary target of cellobiose lipid activity (Puchkov et al. 2002).

The fungal species are known to have different sensitivity to cellobiose lipids (Kulakovskaya et al. 2005, 2009; Mimee et al. 2005). For example, the effective concentrations against basidiomycetes (Filobasidiella neoformans) and ascomycetes (Candida spp.) are $0.03 \mathrm{mM}$ and 0.1-0.4 mM, respectively (Kulakovskaya et al. 2009). The causes of such difference have not yet been investigated. It is unknown whether cultivation conditions, including those affecting the state of the cytoplasmic membrane, influence the sensitivity of target cells.

The cultivation in ethanol-containing media substantially changes the properties of the cytoplasmic membrane of Saccharomyces cerevisiae compared to cultivation in glucose-containing media (Susan et al. 1978; Beaven et al. 1982; Mishra and Prasad 1989; Walker-Caprioglio et al. 1990; Herve A et al. 1994; Kubota et al. 2004). During the cultivation on ethanol, the proportion of ergosterol and mono-unsaturated fatty acid residues in cellular phospholipids increases and the fluidity of membrane decreases (Susan et al. 1978; Beaven et al. 1982; Mishra and Prasad 1989; Walker-Caprioglio et al. 1990; Herve A et al. 1994; Kubota et al. 2004). Inorganic polyphosphate (PolyP) is an energy reserve and a stress-protective compound for microbial cells (Kulaev et al. 2004; Rao et al. 2009; Achbergerová and Nahálka 2011). The content and chain length of these bioactive polymers in Saccharomyces cerevisiae depend on carbon source (Vagabov et al. 2008). So, cultivation on glucose or ethanol allows obtaining the cells of $S$. cerevisiae which differ in membrane fluidity and PolyP content.

The objective of this work was to compare the sensitivity of $S$. cerevisiae cells grown on glucose and ethanol to the fungicide 16 -(tetra-O-acetyl- $\beta$-cellobiosyloxy)-2hydroxyhexadecanoic acid secreted by Cryptococcus humicola (Kulakovskaya et al. 2009; Morita et al. 2011). An attempt was made to assess the relationship between PolyP accumulation and sensitivity to cellobiose lipid.

\section{Results and discussion}

The cellobiose lipid preparation used in the work was obtained from the culture liquid of $\mathrm{Cr}$. humicola strain 9-6 (All-Russian Collection of Microorganisms). Mass spectrometry shows that the major component of the preparation has a molecular mass $781 \mathrm{kDa}$. This compound is a 16-(tetra-O-acetyl- $\beta$-cellobiosyloxy)-2-hydroxyhexadecanoic
Table 1 The viability of the cells of Saccharomyces cerevisiae grown in the media with glucose and ethanol treated with cellobiose lipid

\begin{tabular}{lll}
\hline $\begin{array}{l}\text { Cellobiose lipid, } \\
\text { mg }^{-1}\end{array}$ & \multicolumn{2}{c}{ Cell viability, \% of control } \\
\cline { 2 - 3 } & Glucose grown cells & Ethanol grown cells \\
\hline 0 & 100 & 100 \\
\hline 0.025 & $60 \pm 12$ & - \\
\hline 0.034 & $11 \pm 1.1$ & - \\
\hline 0.050 & $4 \pm 1.7$ & 100 \\
\hline 0.100 & 0.2 & $16 \pm 5.1$ \\
\hline 0.200 & 0.1 & $2 \pm 0.5$ \\
\hline 0.400 & 0 & 1.5 \\
\hline 0.800 & 0 & 0 \\
\hline
\end{tabular}

- not assayed.

acid (cellobiose lipid) according to earlier data (Puchkov et al. 2002; Kulakovskaya et al. 2009) (Figure 1).

The cells of $S$. cerevisiae proved to have different survival capacities at the same cellobiose lipid concentrations depending on the carbon source used. The cells grown on glucose died at a concentration of $0.05 \mathrm{mg} \mathrm{ml}^{-1}$, while the cells grown on ethanol died at $0.2 \mathrm{mg}^{-1}$ (Table 1).

Cellobiose lipid shows fungicidal activity in acidic medium, where it is a weak acid due to dissociation of the carboxyl group (Puchkov et al. 2002; Kulakovskaya et al. 2009). The average values of electrokinetic potential (EKP) were calculated to be $18.8 \pm 1.2$ and $23.6 \pm$ $3.0 \mathrm{mV}$ for the cells of $S$. cerevisiae grown on glucose and ethanol, respectively. It is probable that the high negative surface charge decreases the binding of negatively charged molecules of the fungicide.

One of the known criteria of yeast cytoplasmic membrane integrity damage is the leakage of potassium ions into the medium (Kulakovskaya et al. 2008; Shirai et al. 2009). The effective cellobiose lipid concentrations inducing $\mathrm{K}^{+}$leakage were not different for the cells of $S$. cerevisiae grown on both carbon sources (Figure 2). Consequently, the high stability of $S$. cerevisiae cells grown on ethanol cannot be explained solely by intensification of the barrier functions of the membrane.

The energy of the phosphoester bond in PolyP is similar to that of ATP. PolyP is known to be a factor of microbial cell resistance to stress conditions (Kulaev et al. 2004; Rao et al. 2009; Achbergerová and Nahálka 2011). Hence, the effect of cellobiose lipid on the PolyP, $\mathrm{P}_{\mathrm{i}}$ and ATP content in the cells has been studied.

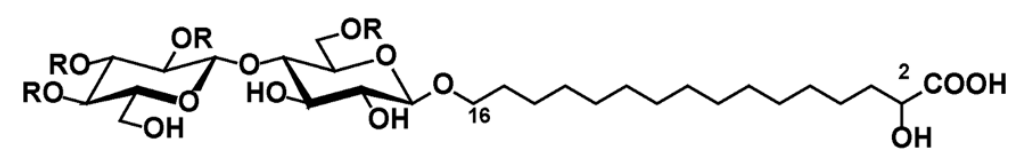

Figure 1 The structure of cellobiose lipid secreted by Cryptococcus humicola strain 9-6. R - acetate. 


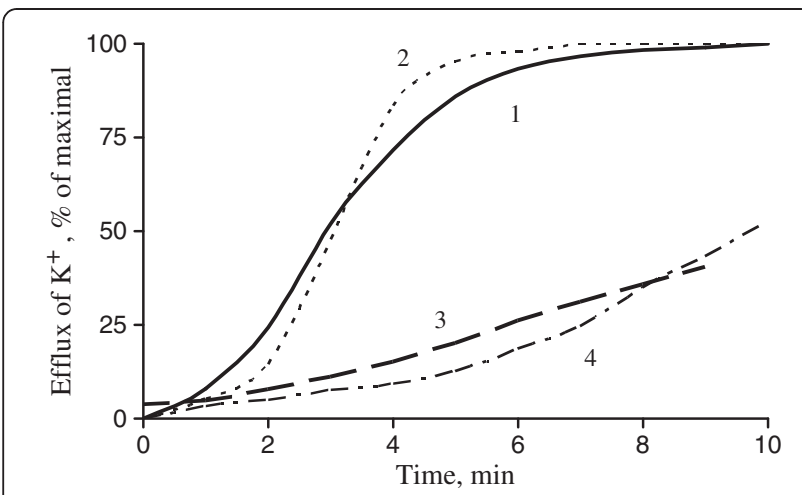

Figure 2 Potassium leakage from the cells of Saccharomyces cerevisiae treated with cellobiose lipid of Cr. humicola: 1 and 3 - the cells were grown in the medium with glucose, 2 and 4 - the cells were grown in the medium with ethanol. The concentration of cellobiose lipid was $0.24 \mathrm{mg} \mathrm{m}^{-1}$ (1 and 2) and $0.12 \mathrm{mg} \mathrm{ml}^{-1}$ (3 and 4).

The experiments were performed under the conditions of PolyP synthesis. The cells with the PolyP content of 50-65 $\mu$ mole $\mathrm{P} / \mathrm{g}$ dry biomass (not shown) were cultivated in the complete medium for $30 \mathrm{~min}$. Then PolyP fractions with different chain lengths were extracted. PolyP accumulation was observed in both media: with glucose and with ethanol (Table 2, Figure 3). PolyP synthesis was almost completely suppressed by cellobiose lipid in the medium with glucose (Figure 3, Table 2) but only by $35 \%$ lower in the medium with ethanol.

The chain length of PolyP of different fractions determined by electrophoresis in PAAG did not depend on the carbon source in the presence and absence of cellobiose lipid (Table 3). The content of longer-chain fractions was higher during cultivation on ethanol (Figure 3 and Table 3 ). During the cultivating on glucose, the $\mathrm{P}_{\mathrm{i}}$ and ATP content decreased in the presence of cellobiose lipid much more than during the cultivation on ethanol (Table 2).

We have also determined the effect of cellobiose lipid on ATP leakage from cells in phosphate-citrate buffer ( $\mathrm{pH} 4.0$ ). The effective glycolipid concentrations were different for the cells grown on glucose and ethanol (Table 4). The addition of glucose decreased the effective concentration of the fungicide only for glucose-grown cells. This effect was not observed in the cells grown on ethanol.
The sensitivity of the cells of $S$. cerevisiae to 16-(tetraO-acetyl- $\beta$-cellobiosyloxy)-2-hydroxyhexadecanoic acid depends on the carbon source used for cell cultivation. The cells grown on ethanol are more resistant to this membrane damaging fungicide. It is probably due to the increase of the negative charge of cell surface (EKP) during cultivation on ethanol and to the change in membrane lipid composition. However, the effects of cellobiose lipid on potassium leakage were similar for the cells grown in the media with glucose or ethanol. It suggests the existence of additional factors increasing the resistance of yeast grown on ethanol to cellobiose lipid. We speculate the long-chained polyP participate in the restoring of viability of ethanol-grown cells after treatment with the cellobiose lipid.

\section{Conclusion}

The sensitivity of yeast cells to antifungal cellobiose lipids depends on culture conditions especially on carbon source. The peculiarities of growth conditions of target microorganisms should be taken into account when assessing effective concentrations of these new fungicidal compounds.

\section{Materials and methods}

\section{Strains and growth conditions}

The yeast Saccharomyces cerevisiae strain VKM Y-1173 was grown in a shaker in the Reader medium with $0.2 \%$ yeast extract, $2 \%$ glucose (120 r.p.m.), or $1 \%$ ethanol (200 r.p.m.). The medium contained $\left(\mathrm{g} \mathrm{l}^{-1}\right)$ : $\left(\mathrm{NH}_{4}\right)_{2} \mathrm{SO}_{4}$, 3; $\mathrm{MgSO}_{4}, 0.7 ; \mathrm{Ca}\left(\mathrm{NO}_{3}\right)_{2}, 0.4 ; \mathrm{NaCl}, 0.5 ; \mathrm{KH}_{2} \mathrm{PO}_{4}, 1$; $\mathrm{K}_{2} \mathrm{HPO}_{4}, 0.1 ;\left(\mathrm{NH}_{4}\right)_{2} \mathrm{SO}_{4} \cdot \mathrm{FeSO}_{4} \cdot 6 \mathrm{H}_{2} \mathrm{O}, 0.00025$; and trace elements (Vagabov et al. 2000).

Polyphosphate (PolyP) biosynthesis was studied using the cells with low PolyP levels grown in a phosphatefree medium as described in (Vagabov et al. 2000). Then the cells were cultivated in complete medium for $0.5 \mathrm{~h}$. Biomass samples were harvested at $3000 \mathrm{~g}$ for $10 \mathrm{~min}$, washed twice with distilled water at $4^{\circ} \mathrm{C}$, and used for PolyP extraction. Dry cell mass was determined after drying cell aliquots at $85^{\circ} \mathrm{C}$ under vacuum.

\section{Purification of cellobiose lipids}

The cellobiose lipid of the yeast Cryptococcus humicola 9-6 (All-Russian Collection of Microorganisms, VKM) was obtained as described (Kulakovskaya et al. 2009).

Table 2 The effect of cellobiose lipid on the content of $P_{i}$, PolyP and ATP ( $\mu \mathrm{mol} \mathrm{g}^{-1}$ dry biomass) in the cells of $S$. cerevisiae under PolyP synthesis: the cells after $P_{i}$ starvation were cultivated in the complete medium with $10 \mathrm{mM} P_{i}$ for $\mathbf{3 0} \mathrm{min}$

\begin{tabular}{|c|c|c|c|c|c|c|}
\hline \multirow{3}{*}{$\begin{array}{l}\text { Culture condition } \\
\text { Control }\end{array}$} & \multirow{2}{*}{\multicolumn{2}{|c|}{$\begin{array}{c}\text { Glucose ethanol } \\
P_{i}\end{array}$}} & \multirow{2}{*}{\multicolumn{2}{|c|}{$\begin{array}{c}\text { Glucose ethanol } \\
\text { PolyP }\end{array}$}} & \multirow{2}{*}{\multicolumn{2}{|c|}{$\begin{array}{c}\text { Glucose ethanol } \\
\text { ATP }\end{array}$}} \\
\hline & & & & & & \\
\hline & 45 & 41 & 870 & 825 & 5.1 & 13 \\
\hline Cellobiose lipid, $0.05 \mathrm{mg} \mathrm{m}^{-1}$ & 3.4 & 20 & 80 & 560 & 1.2 & 6.0 \\
\hline
\end{tabular}




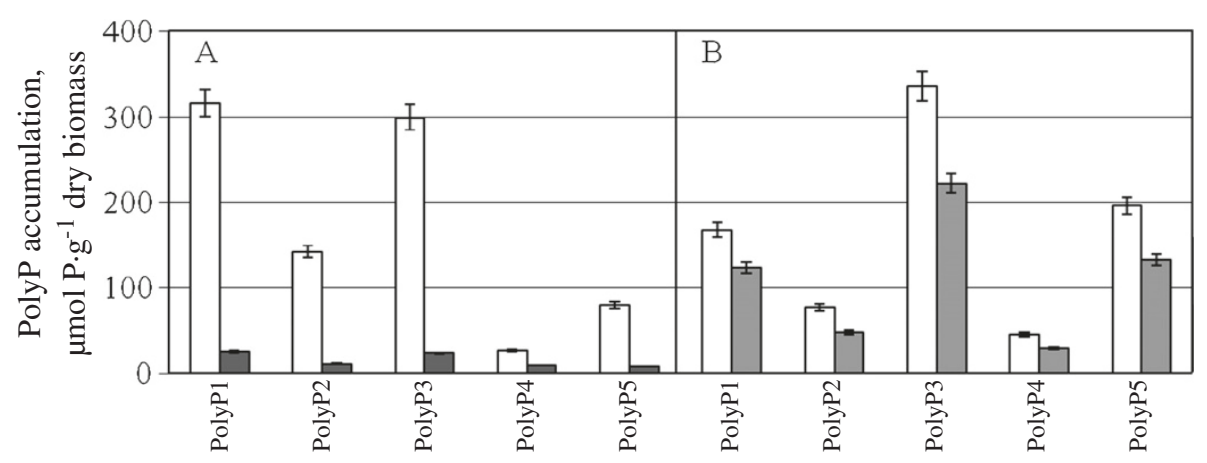

Figure 3 The accumulation of different fraction of inorganic polyphosphate (PolyP) in the cells of Saccharomyces cerevisiae for 30 min of cultivation in phosphate-rich medium with glucose (A) and ethanol (B). ( $\square$ ) - control, ( $\square$ ) - in the presence of cellobiose lipid, $0.05 \mathrm{mg} \mathrm{ml}^{-1}$.

After the cultivation, the culture supernatant was separated by centrifugation at $5000 \mathrm{~g}$ for $40 \mathrm{~min}$, filtered through a Whatman glass fiber filter GF/A from SigmaAldrich Rus (Moscow, Russia), and lyophilized. The residue was extracted with methanol for four to five days at $5^{\circ} \mathrm{C}$ and filtered. The filtrate was evaporated at $50^{\circ} \mathrm{C}$, and the resulting product was suspended in deionized water. The suspension was kept for $24 \mathrm{~h}$ at $5^{\circ} \mathrm{C}$, and the resulting precipitate was separated by filtration through a glass filter, washed twice with cooled deionized water, and dissolved in methanol. The concentration of glycolipids was determined by weighing after methanol evaporation. In the course of purification, the antifungal activity was assayed by placing the aliquots of preparations on glucose-peptone agar (GPA) containing $0.5 \%$ glucose, $0.2 \%$ yeast extract, $0.25 \%$ peptone, $2 \%$ agar, $0.04 \mathrm{M}$ citrate-phosphate buffer, $\mathrm{pH} 4.0$ and inoculated with $S$. serevisiae.

\section{ESI-MS analysis}

The ESI-MS spectra were recorded with a Finnigan MAT LCQ (San Jose, CA, USA) mass spectrometer as described earlier for positive ions (Kulakovskaya et al. 2005, 2009. For direct (syringe) inlet, the methanol

Table 3 Polyphosphates in Saccharomyces cerevisiae after 30 min cultivation in the media with glucose or ethanol: the average chain length and proportion of PolyP of different fractions

\begin{tabular}{lccc}
\hline Fraction & $\begin{array}{c}\text { Average chain } \\
\text { length }(\mathbf{n})\end{array}$ & \multicolumn{2}{c}{$\%$ of total PolyP content } \\
\cline { 3 - 4 } & 15 & Glucose & Ethanol \\
\hline PolyP1 & 25 & 37 & 20 \\
\hline PolyP2 & 65 & 16 & 9 \\
\hline PolyP3 & 75 & 35 & 41 \\
\hline PolyP4 & $>200$ & 3 & 6 \\
\hline PolyP5 & 9 & 24 \\
\hline
\end{tabular}

The cells after $P_{i}$ starvation were cultivated in the complete medium with $10 \mathrm{mM} \mathrm{P}$. solution of a sample was injected at $10 \mu \mathrm{L} / \mathrm{min}$. MS spectra were measured in positive mode.

\section{Inorganic polyphosphate (PolyP) assay}

Five separate polyP fractions differ in the chain length were obtained from Saccharomyces cerevisiae cells as described in (Vagabov et al. 2000). Acid-soluble polyphosphates (PolyP1) were extracted with $0.5 \mathrm{~N} \mathrm{HClO}_{4}$. Salt-soluble polyphosphates (PolyP2) were extracted with saturated $\mathrm{NaClO}_{4}$ solution. Two fractions of alkali-soluble polyphosphates (PolyP3 and PolyP4) were extracted with the weak $\mathrm{NaOH}$ solution ( $\mathrm{pH}$ was adjusted to 9-10) and $0.05 \mathrm{M}$ $\mathrm{NaOH}$ ( $\mathrm{pH}$ 12), respectively. All extractions were performed twice at $0^{\circ} \mathrm{C}$ under stirring for $10 \mathrm{~min}$. The PolyP contents in the fractions PolyP1, PolyP2, PolyP3 and PolyP4 were quantified as a difference in $\mathrm{P}_{\mathrm{i}}$ amounts before and after hydrolysis of the samples in $1 \mathrm{~N} \mathrm{HCl}$ for $10 \mathrm{~min}$ at $100^{\circ} \mathrm{C}$. The level of PolyP5 fraction was determined by treating residual material with $0.5 \mathrm{~N} \mathrm{HClO}_{4}$ at $90^{\circ} \mathrm{C}$ twice for $20 \mathrm{~min}$ and assaying the released $\mathrm{P}_{\mathrm{i}} \cdot \mathrm{P}_{\mathrm{i}}$ was determined according to (Vagabov et al. 2000). The data in the tables and figures are the average values of three experiments.

The chain length of PolyP from different fractions was determined by electrophoresis in polyacrylamide gel according to (Kumble and Kornberg 1995). For PolyP5

Table 4 The concentrations of cellobiose lipid ( $\mathrm{mg} \mathrm{ml}^{-1}$ ) causes the maximal leakage of ATP in phosphate-citrate, pH 4.0 from S. cerevisiae cells

\begin{tabular}{lcc}
\hline Incubation medium & $\begin{array}{c}\text { Cells grown in } \\
\text { medium with } \\
\text { glucose }\end{array}$ & $\begin{array}{c}\text { Cells grown in } \\
\text { medium with } \\
\text { ethanol }\end{array}$ \\
\cline { 2 - 3 } $\begin{array}{l}\text { The concentration of } \\
\text { cellobiose lipid }\end{array}$ & 0.6 & 0.6 \\
\hline $0.04 \mathrm{M}$ citrate-phosphate, $\mathrm{pH} \mathrm{4.0}$ & 0.6 & 0.15 \\
\hline \begin{tabular}{l}
$\mathrm{pH}$ 4.0, $2 \%$ glucose \\
\hline
\end{tabular} & &
\end{tabular}


electrophoresis, residual biomass was extracted with distilled water for $12 \mathrm{~h}$ (Vagabov et al. 2008). PolyP standards with the average chain lengths of 15, 25, 45, 75 phosphate residues were from Sigma (St Louis, USA), and with the average chain lengths of 208 phosphate residues were from Monsanto (St Louis, USA).

\section{ATP assay}

The ATP content in the cells was assayed after treating biomass samples with dimethylsulfoxide $(0.2 \mathrm{ml} / 25-50 \mathrm{mg}$ of wet biomass). The effects of cellobiose lipids on ATP leakage from the cells was assayed as described (Kulakovskaya et al. 2003). ATP was assayed by the luciferin-luciferase method using a Sigma assay kit and a LKB 1250 Luminometer (Sweden).

\section{Potassium ion leakage}

The leakage of $\mathrm{K}^{+}$from the yeast cells was registered with a $\mathrm{K}^{+}$-selective electrode (Orion, USA). The measurements were made in a thermostatically controlled $2.5 \mathrm{ml}$ cell at $25^{\circ} \mathrm{C}$ under stirring. The measuring medium containing $0.01 \mathrm{M}$ citrate-phosphate buffer, $\mathrm{pH}$ 4.0, was injected with $50 \mu \mathrm{l}$ of cell suspension to a final cell concentration of 6-6.5 $\cdot 10^{8} \mathrm{ml}^{-1}$. The maximum quantity of $\mathrm{K}^{+}$found in the medium was taken as $100 \%$.

\section{Measurement of EKP (electrokinetic potential)}

The cells were suspended in $0.01 \mathrm{M}$ citrate buffer, $\mathrm{pH}$ 4.0, to a concentration of $10^{7}-5 \times 10^{7}$ cells $\mathrm{ml}^{-1}$. The EKP of yeast cells was measured with a Zetasizez nano ZS (Malvern, Great Britain) by the method of laser Doppler spectroscopy at $25^{\circ} \mathrm{C}$. The average EKP value was calculated from three repeated measurements in each population of yeast cells.

\section{The assay of cell viability}

Yeast cell viability assay was performed as follows. The starting cell suspension was diluted in distilled water (1:100). Then the cells were treated with different cellobiose lipid concentrations $\left(0.025\right.$ to $\left.0.8 \mathrm{mg} \mathrm{ml}^{-1}\right)$. The incubation mixture contained $0.5 \mathrm{ml}$ of $0.04 \mathrm{M}$ citratephosphate buffer, $\mathrm{pH} 4.0$, and $0.1 \mathrm{ml}$ of cell suspension. The mixture without cellobiose lipid was used as a control (100\% viability). After the treatment, the cells were incubated at $30^{\circ} \mathrm{C}$ for $1 \mathrm{~h}$. Then the cell suspensions were diluted in the citrate-phosphate buffer to different ratios and deposited on Petri dishes. The Petri dishes were incubated at $28^{\circ} \mathrm{C}$ for 3 days and the number of colonies was calculated.

All experiments were performed in triplicate. The biochemicals except those which are listed separately were obtained from Sigma-Aldrich-Rus (Moscow, Russia).

\section{Abbreviations}

PolyP, Inorganic polyphosphate; 16 -(tetra-O-acetyl- $\beta$-cellobiosyloxy)-2-

hydroxyhexadecanoic acid, Cellobiose lipid.

\section{Competing interests}

The authors declare that they have no competing interests.

\section{Authors' contributions}

LVT carried out the extraction and characterization of polyphosphates. EVK carried out the purification and characterization of cellobiose lipid and cell viability assay. AYI carries out the potassium leakage experiments. NVP carried out electrokinetic study. TVK participated in the design of the study and performed the statistical analysis. VMV and ISK conceived of the study, and participated in its design and coordination and helped to draft the manuscript. All authors read and approved the final manuscript.

\section{Acknowledgements}

The work was supported by the Russian Foundation for Basic Research (grants 11-04-01009 and 12-04-32138). We are thankful to Dr. W.I. Golubev for providing of the strain 9-6 of Cr. humicola and to E. Makeeva for the help in preparation of the manuscript.

\section{Author details}

${ }^{1}$ Skryabin Institute of Biochemistry and Physiology of Microorganisms, Russian Academy of Sciences, Pushchino, Moscow Region 142290, Russia. ${ }^{2}$ Institute of Cell Biophysics, Russian Academy of Sciences, Pushchino, Moscow Region 142290, Russia.

Received: 18 April 2012 Accepted: 10 September 2012 Published: 25 September 2012

\section{References}

Achbergerová L, Nahálka J (2011) Polyphosphate - an ancient energy source and active metabolic regulator. Microb Cell Fact 10:63-70

Beaven JM, Charpentier C, Rose AH (1982) Production and tolerance of ethanol in relation to phospholipid fatty-acyl composition in Saccharomyces cerevisiae. J Gen Microbiol 128:1447-155

Bölker M, Basse CW, Schirawski J (2008) Ustilago maydis secondary metabolismfrom genomics to biochemistry. Fungal Genet Biol 45:588-593

Cameotra SS, Makkar RS (2004) Recent applications of biosurfactants as biological and immunological molecules. Cur Opin Microbiol 7:262-266

Golubev WI (2006) Antagonistic interactions among yeast. In: Rosa CA, Peter G, (eds) Biodiversity and Ecophysiology of the Yeasts. Berlin Verlag, Berlin, pp 197-219

Hammami W, Chain F, Michaud D, Bélanger RR (2010) Proteomic analysis of the metabolic adaptation of the biocontrol agent Pseudozyma flocculosa leading to glycolipid production. Proteome Sci 8:7

Hammami W, Castro CQ, Rémus-Borel W, Labbé C, Bélanger RR (2011) Ecological Basis of the Interaction between Pseudozyma flocculosa and Powdery Mildew Fungi. Appl Environ Microbiol 77:926-933

Herve A, Rousseaux I, Charpentier C (1994) Relationship between ethanol tolerance, lipid composition and plasma membrane fluidity in Saccharomyces cerevisiae and Kloeckera apiculata. FEMS Microbiol Lett 124:17-22

Kitamoto D, Isoda Y, Nakahara T (2002) Functions and potential applications of glycolipid biosurfactants - from energy-saving material to gene delivery carriers. J Biosci Bioeng 94:187-191

Kubota S, Takeo I, Kume K, Kanai M, Shitamukai A, Mizunuma M, Miyakawa T, Shimoi H, lefuji H, Hirata D (2004) Effect of ethanol on cell growth of budding yeast: genes that are important for cell growth in the presence of ethanol. Biosci Biotechnol Biochem 68:968-972

Kulaev IS, Vagabov VM, Kulakovskaya TV (2004) The Biochemistry of Inorganic Polyphosphates. John Wiley \& Sons Ltd., Chichester

Kulakovskaya TV, Kulakovskaya EV, Golubev WI (2003) ATP leakage from yeast cells treated by extracellular glycolipids of Pseudozyma fusiformata. FEMS Yeast Res 3:401-404

Kulakovskaya TV, Shashkov AS, Kulakovskaya EV, Golubev WI (2005) Ustilagig acid secretion by Pseudozyma fusiformata strains. FEMS Yeast Res 5:919-923

Kulakovskaya EV, Ivanov AY, Kulakovskaya TV, Vagabov VM, Kulaev IS (2008) Effects of cellobiose lipid B on Saccharomyces cerevisiae cells: K + leakage and inhibition of polyphosphate accumulation. Microbiology 77:288-292 
Kulakovskaya T, Shashkov A, Kulakovskaya E, Golubev W, Zinin A, Tsvetkov Y, Grachev A, Nifantiev N (2009) Extracellular cellobiose lipid from yeast and their analogues: structures and fungicidal activities. J Oleo Sci 58:133-140

Kumble KD, Kornberg A (1995) Inorganic polyphosphate in mammalian cells and tissues. J Biol Chem 270:5818-5822

Mimee B, Labbe C, Pelletier R, Belanger RR (2005) Antifungal activity of flocculosin, a novel glycolipid isolated from Pseudozyma flocculosa. Antimicrob Agents Chemother 49:1597-1599

Mishra P, Prasad R (1989) Relationship between ethanol tolerance and fatty-acyl composition of Saccharomyces cerevisiae. Appl Microbiol Biotechnol 30:294-308

Morita T, Ishibashi Y, Fukuoka T, Imura T, Sakai H, Abe M, Kitamoto D (2011) Production of glycolipid biosurfactants, cellobiose lipids, by Cryptococcus humicola JCM 1461 and their interfacial properties. Biosci Biotechnol Biochem 75:1597-1599

Puchkov EO, Zahringer U, Lindner B, Kulakovskaya TV, Seydel U, Wiese A (2002) Mycocidal, membrane-active complex of Cryptococcus humicola is a new type of cellobiose lipid with detergent features. Biochim Biophys Acta (Biomembranes) 1558:161-170

Rao NN, Gomez-Garcia MR, Kornberg A (2009) Inorganic polyphosphate: essential for growth and survival. Ann Rev Biochem 78:605-647

Rodrigues L, Banat IM, Teixeira J, Oliveira R (2007) Biosurfactants: potential application in medicine. J Antimicrob Chemother 57:609-618

Shirai A, Sumimoto T, Kurimoto M, Maseda H, Kourai H (2009) The mode of the antifungal activity of gemini-pyridinium salt against yeast. Biocontrol Sci 14:13-20

Susan TD, Hossack JA, Rose AH (1978) Plasma-membrane lipid composition and ethanol tolerance in Saccharomyces cerevisiae. Arch Microbiol 117:239-245

Teichmann B, Linne U, Hewald S, Marahiel MA, Bölker M (2007) A biosynthetic gene cluster for a secreted cellobiose lipid with antifungal activity from Ustilago maydis. Mol Microbiol 66:525-533

Vagabov VM, Trilisenko LV, Kulaev IS (2000) Dependence of inorganic polyphosphate chain length on the orthophosphate content in the culture medium of the yeast Saccharomyces cerevisiae. Biochemistry-Moscow+ 65:349-355

Vagabov VM, Trilisenko LV, Kulakovskaya TV, Kulaev IS (2008) Effect of carbon source on polyphosphate accumulation in Saccharomyces cerevisiae. FEMS Yeast Res 8:877-882

Walker-Caprioglio HM, Casey WM, Parks LW (1990) Saccharomyces cerevisiae Membrane sterol modifications in response to growth in the presence of ethanol. Appl Environ Microbiol 56:2853-2857

doi:10.1186/2193-1801-1-18

Cite this article as: Trilisenko et al:: The antifungal effect of cellobiose lipid on the cells of Saccharomyces cerevisiae depends on carbon source. SpringerPlus 2012 1:18.

\section{Submit your manuscript to a SpringerOpen ${ }^{\circ}$ journal and benefit from:}

- Convenient online submission

- Rigorous peer review

- Immediate publication on acceptance

- Open access: articles freely available online

- High visibility within the field

- Retaining the copyright to your article

Submit your next manuscript at $\gg$ springeropen.com 